\title{
JEKK
}

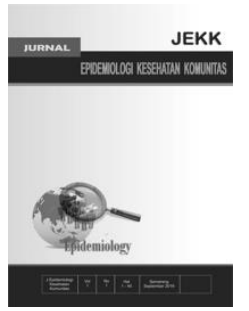

\section{Toxoplasmosis and Cerebral Toxoplasmosis in HIV/AIDS Patients in Kariadi Hospital, Semarang}

\author{
Dauda Sanni Hassana ${ }^{*}$, Suharyo Hadisaputro ${ }^{* *}$, Muchlis Achsan Udji Sofro ${ }^{* * *}$ \\ "Master of Epidemiology, School of Postgraduate, University of Diponegoro, Semarang, Indonesia. \\ ${ }^{* *}$ Faculty of Medicine, , University of Diponegoro, Semarang, Indonesia. \\ **** Kariadi Hospital, Semarang, Indonesia.
}

\begin{abstract}
Background: Toxoplasmosis is an infection caused by Toxoplasma gondii, which affects the central nervous system resulting to a fatal situation in HIV patients, especially at the advanced stage. Cerebral toxoplasmosis (CT) is the clinical presentation of toxoplasmosis in individuals with HIV/AIDS. The study was carried out to describe the prevalence of toxoplasmosis and cerebral toxoplasmosis in HIV/AIDS patients attending the hospital setting used in the study.

Methods: Patients medical records were checked and analyzed for demographic characteristics as well as to determine the results of toxoplasma IgG tests for HIV/AIDS patients as well as those who had cerebral toxoplasmosis. The study was descriptive.

Result: Out of the 158 HIV/AIDS patients tested, 129 (81.6\%) were positive for T. gondii. A $62.0 \%$ prevalence rate was recorded for the male subjects while $19.6 \%$ prevalence rate was recorded for the female subjects although there was no significant difference $(\mathrm{X} 2=0.58, \mathrm{P}>0.05)$. $69.3 \%$ of the total population studied had cerebral toxoplasmosis with a prevalence rate of $74.3 \%$ and $25.3 \%$ ) in male and female respectively. A higher prevalence was recorded from the age group $>30$ years without significant difference $(\mathrm{X} 2=0.74, \mathrm{P}>0.05)$.

Conclusion: More research is required to know the exact prevalence of the parasite in this group of individuals since not all the patients were tested.
\end{abstract}

Keywords: Toxoplasmosis; HIV/AIDS; Cerebral Toxoplasmosis; RSUP Dr. Kariadi; Semarang.

*Corresponding author,daudasannihassana@gmail.com 


\section{Introduction}

Toxoplasmosis is caused by an infection with the coccidian Toxoplasma gondii, and it is considered as a significant public health problem worldwide, causing a chronic condition where most of the cases are asymptomatic and remains undetected. ${ }^{1}$ It infects approximately one-third of the world's population $^{2}$ with these infections having a significant consequence affecting mortality and quality of life. It frequently affects the central nervous system resulting to a fatal situation in HIV patients, especially at the advanced stage $^{3,4}$. However, the incidence of this disease has decreased due to the introduction of antiretroviral treatment (ART). ${ }^{5}$ Cerebral toxoplasmosis $(\mathrm{CT})$ is the clinical presentation of toxoplasmosis in individuals with HIV/AIDS, and it has been proven in $35 \%$ of HIV/AIDS patients to be an HIV-indicative disease while also proven in $75 \%$ of such cases to be an AIDS-defining disease. ${ }^{6}$ The reactivation of the parasite thereby bringing about cerebral toxoplasmosis is through a mechanism where some vital cells such as CD4 cells are depleted as well as decreased production of others. $^{7}$

Prevalence rate of Toxoplasma infection among HIV positive individuals worldwide, varies from $3 \%$ to $97 \% .{ }^{8}$ In Southeast Asia, the seroprevalence of toxoplasmosis was recorded to be low in countries which a climate described as tropical monsoon, e.g. Cambodia, Thailand, Vietnam, Laos etc. but $59.7 \%$ of inhabitants in Malaysia were $\mathrm{T}$. gondii seropositive. ${ }^{9}$ The seroprevalence of toxoplasmosis in Indonesia also appears to vary in different regions, e.g. in Surabaya, the prevalence was found to be $63 \%$, in Jakarta, it was $75 \%$, in Yogyakarta it was $61.5 \%$, and in Central Java, it was $62.54 \% .^{10,11}$ There is a paucity of knowledge about infection due to Toxoplasma gondii among individuals positive for HIV in RSUP Dr. Kariadi Semarang, which is one of the leading hospitals in the region having a high prevalence of HIV/AIDS patients. Herein, we describe the prevalence of toxoplasmosis and cerebral toxoplasmosis in HIV/AIDS patients who attended this hospital setting within the periods of $2015-2019$.

\section{Methods}

\section{Study Population}

All HIV/AIDS patients aged 18 years and above who received medical care, between 2015 and 2019 at RSUP Dr. Kariadi Hospital Semarang were the subjects for this study. This hospital was chosen because it is one of the leading hospitals in Indonesia, which provides care and services to HIV/AIDS patients. 101 HIV-positive patients were diagnosed with cerebral toxoplasmosis during the study period, seen from a lesion having a mass effect on cerebral tomography imaging and a serum antibody to $T$. gondii while 57 patients were HIV positive but with no cerebral toxoplasmosis, giving a total of 158 subjects used in the study.

\section{Study design and Data Collection}

This study was a descriptive clinical study, based on retrospectively collected information and a standardization and clinical validation of a laboratory assay. The study was approved by the research and ethics committee of RSUP Dr. Kariadi hospital Semarang, Central Java province in Indonesia. Written informed consent was also obtained from the hospital to access the medical records of the patients since the researcher did not meet with the patients. Demographic characteristics, clinical and laboratory data were all collected from the medical records for the specific purpose of the study at the RSUP Dr. Kariadi hospital, between November 2019 and January 2020.

\section{Statistical Analyses}

Data collected and used in this study were all checked for accuracy, completeness and consistency. A computer program SPSS (Statistical Package for Social Sciences, version 22.0) for Windows was used to analyze the data collected. In other to compare Toxoplasma gondii infection among the variables, the Chi-square test was used. This test is useful in testing the relationship or effect of two variables as well as in measuring the strength of the relationship between two variables. The $\mathrm{p}<0.05$, i.e. $5 \%$ level of significance was used in the study. 


\section{Result}

HIV/AIDS patients who attended RSUP Dr. Kariadi hospital from 2015-2019 who were tested for anti-toxoplasma antibodies was searched for in the hospital medical records, and the results were carefully analyzed. A total of 158 adult patients' record was used in this study, with their ages ranging from 18 to 63 . The CD4 counts of all patients were also recorded with most of the patients having CD4 counts less than 50cell/ul $(66.46 \%)$ while those with CD4 counts higher than 100 were just $12.6 \%$ with the others having counts between fifty and hundred cells/microliter. Of the 158 HIV/AIDS patients tested, 129 (81.6\%) were positive for T. gondii (Table 2). Gender wise, the prevalence rates were $98(62.0 \%)$ for the male subjects, and the prevalence rate for the females was 31(19.6). The prevalence for $\mathrm{T}$. gondii did not differ significantly between sexes.

Table 1. Age and gender data for the subjects

\begin{tabular}{lcc}
\hline $\begin{array}{l}\text { Age } \\
\text { (years) }\end{array}$ & Number of Individuals & Total \\
\hline & Male & Female
\end{tabular}

\begin{tabular}{lrrr}
18 to 29 & 30 & 15 & 45 \\
30 to 39 & 36 & 15 & 51 \\
40 to 49 & 36 & 7 & 43 \\
$>=50$ & 16 & 3 & 19 \\
\hline Total & 188 & 40 & 158 \\
\hline
\end{tabular}

Table 2. Prevalence of T. gondii in HIV/AIDS patients in RSUP Dr Kariadi Hospital Semarang

\begin{tabular}{lccc}
\hline Sex & $\begin{array}{c}\text { No } \\
\text { tested }\end{array}$ & \multicolumn{2}{c}{ Toxoplasma positivity } \\
\cline { 3 - 4 } & & No & $\%$ \\
\hline Male & 118 & 98 & 76.0 \\
Female & 40 & 31 & 24.6 \\
\hline Total & 158 & 129 & 100 \\
\hline $\mathrm{X}^{2}=0.58(\mathrm{P}>0.05)$ & &
\end{tabular}

Since IgG positivity and subsequent reactivation of the parasite leads to cerebral toxoplasmosis in these patients, the prevalence of cerebral toxoplasmosis was further examined. Of the 158 patients tested, only 101 $(63.9 \%)$ were positive for cerebral toxoplasmosis. The prevalence rate in men was $75(74.3 \%)$ while in ladies, it was $26(25.3 \%)$ (Table 3). Age-wise, the patients were divided into two groups ( $<30$ and $>30$ years) and a higher prevalence rate of $72.3 \%$ was gotten from the age group greater than 30years (Table 4) although it was not statistically associated with cerebral toxoplasmosis.

Table 3. Prevalence of Cerebral Toxoplasmosis in HIV/AIDS patients in relation to gender

\begin{tabular}{lccc}
\hline Sex & $\begin{array}{c}\text { No } \\
\text { tested }\end{array}$ & $\begin{array}{c}\text { Cerebral } \\
\text { Toxoplasmosis } \\
\text { positivity }\end{array}$ \\
\hline Male & 118 & 75 & $\%$ \\
Female & 40 & 26 & 25.7 \\
\hline Total & 158 & 101 & 100 \\
\hline
\end{tabular}

Table 4. Prevalence of Cerebral Toxoplasmosis in HIV/AIDS patients in relation to age group

\begin{tabular}{lccc}
\hline Age & No tested & \multicolumn{2}{c}{$\begin{array}{c}\text { Cerebral } \\
\text { Toxoplasmosis } \\
\text { positivity }\end{array}$} \\
\hline & & No & $\%$ \\
\cline { 3 - 4 }$<30$ & 46 & 28 & 27.7 \\
$>30$ & 112 & 73 & 72.3 \\
\hline Total & 158 & 101 & 100 \\
\hline $\mathrm{X}^{2}=0.74(\mathrm{P}>0.05)$ & &
\end{tabular}

\section{Discussion}

1,160 new HIV infected patients visited the hospital during the study period of which only 158 patients were tested for antitoxoplasma antibodies this is because, in this health care setting, only patients who present signs and symptoms for toxoplasma infection 
were tested. The seroprevalence of Toxoplasma IgG antibodies in HIV/aids patients in RSUP Dr. Kariadi was found to be $81.6 \%$ while those who had the reactivation of this parasite, thereby resulting to cerebral toxoplasmosis was $63.9 \%$. The prevalence of $T$. gondii gotten in this research was lower than reports observed by Yulia et al. . ${ }^{12}$ and Amuta et al. ${ }^{13}$ where they reported a seroprevalence of $35.2 \% 10.8 \%$ in VCT clinic at the Dr Moewardi General Hospital in Surakarta, Indonesia and Makurdi Nigeria respectively.

This high prevalence could be due to the fact that RSUP Dr. Kariadi is the biggest hospital caring for individuals with HIV/AIDS in the region, and as such, most of the patients are found here. It could also be due to the limited number of the sample used in the study. Other studies from other Asian countries have also reported high seroprevalence of $T$. gondii in HIV patients although the result from the present study is still higher than that reported by Nissapatorn et al. $(51.2 \%)^{14}$ and Minoo et al. $(49.7 \%)^{15}$ in Kuala Lumpur and Iran respectively. Gender wise, the prevalence was higher $(62.0 \%)$ in males than in females $(19.6 \%)$. This could be due to the fact that men may be more actively involved in risk activities which expose them to this parasite, although the result was not statistically significant. Therefore, the result is in line with the result obtained by of Nissapatorn et $\mathrm{al}^{14}$ were a significantly higher positive rate was reported in men $(48.0 \%)$ as compared to females $(9.3 \%)$ in HIV infected patients at Hospital Kuala Lumpur, Malaysia, but the result disagrees with result obtained from Yulia et $\mathrm{al}^{12}$ where a no significant difference was reported between males and females.

The prevalence rate of cerebral toxoplasmosis in men was also higher (74.3\%) than in ladies $(25.3 \%)$. This could be due to the fact that ladies tend to report early enough to hospitals for treatment than their male counterparts who wait until the sickness deteriorates. A higher prevalence rate of $72.3 \%$ was also observed from the age group greater than 30years although it was not statistically associated with cerebral toxoplasmosis. This indicates that the patients who fall in this age group are likely to be more predisposed to cerebral toxoplasmosis infection than the other age group which could be as a result of low CD4 counts, non-compliance to taking ARV and maybe consumption of raw or undercooked meats and vegetables like satay which is a common type of meat consumed here in Indonesia.

The small number of the sample used is also another limitation, and this was as a result of the fact that most HIV infected patients in this setting are not tested for toxoplasma IgG.

\section{Conclusion}

In conclusion, testing for antibodies against $T$. gondii is highly suggested in HIV/AIDS patients in other to reduce the amount of patients who graduate to cerebral toxoplasmosis.

\section{Acknowledgement}

This research was supported by a research studentship from KNB Kemenristek Dikti, Indonesia. We thank all the staffs of the medical records unit of RSUP Dr. Kariadi Semarang for granting permission to get and analyse the records containing the data of subjects used in this study.

\section{References}

1. Pappas, G., Roussos, N. and Falagas, M.E. 2009. Toxoplasmosis snapshots: Global status of Toxoplasma gondii seroprevalence and implications for pregnancy and congenital toxoplasmosis. International Journal for Parasitology. 39 (12):1385-94.

2. Tenter, A.M., Heckeroth, A.R. and Weiss, L.M. 2000. Toxoplasma gondii: from animals to humans. Int $\mathrm{J}$ Parasitol; 30: 1217-1258.

3. Naba, M.R., Kanafani, Z.A., Awar, G.N., Kanj, S.S. 2010. Profile of opportunistic infections in HIV-infected patients at a tertiary care centre in Lebanon. J Infect Public Health. 3: 130-133. 
4. Pott, H. and Castelo, A. 2013. Isolated cerebellar toxoplasmosis as a complication of HIV infection. Int J STD AIDS. 24 (1):70-2.

5. Mayor, A.M., Fernandez S.D.M., Dworkin, M.S., Rios-Olivares E., HunterMellado, R.F. 2011. Toxoplasmic encephalitis in an AIDS cohort at Puerto Rico before and after highly active antiretroviral therapy (HAART). Am J Trop Med Hyg. 84: 838-841.

6. Pereira-Chioccola, V.L., Vidal, J.E., Su, C. 2009. Toxoplasma gondii infection and cerebral toxoplasmosis in HIV-infected patients. Future Microbiol. 4: 1363-1379

7. Basavaraju A. 2016. Toxoplasmosis in HIV infection: an overview. Trop Parasitol. 6: 129-35.

8. Minoo, M., Farhad, M., Sara, J., Seyed, A., Duman, S., Fatemeh, F., Hossain, J., Mahboubeh, H. 2011. Seroprevalence of Toxoplasmosis in HIV+/AIDS Patients in Iran. Acta Med Iranica. 49: 213-218

9. Ahmad, A.F., Ngui, R., Muhammad, A. R., Lim, Y. A., Rohela, M. 2014. Current status of parasitic infections among Pangkor Island community in Peninsular Malaysia. Trop. Biomed. 31: 836-843.

10. Soedarto. 2011. Buku Ajar Parasitologi Kedokteran. Jakarta; SagungSeto,.

11. Retmanasari A. 2015. Analisis Spatial dan Faktor Risiko Toksoplasmosis di Jawa Tengah Bagian Selatan. Tesis. Universitas Gadjah Mada, Yogyakarta.

12. Yulia, S., Sri, H., Irvan, R. and Afiono, A.P. 2015. Toxoplasma and viral antibodies among HIV patients and Inmates in Central Java, Indonesia. South East Asian J trop Med public health. 46(6).

13. Amuta, E.U., Amali, O., Jacob, S.E. and Houmsou, R.S. 2012. Toxoplasma gondii IgG antibodies in HIV/AIDS patients attending hospitals in Makurdi metropolis, Benue state, Nigeria. Int J Med Biomed Res. 1 (3): 186-192.

14. Nissapatorn, V., Lee, C., Quek, K.F., Leong, C.L., Mahmud, R. and Abdullah, K.A. 2004. Toxoplasmosis in HIV/AIDS patients: a current situation. Jpn J Infect Dis. 57: 160-165.

15. Minoo, M., Farhad, M., Sara, J., Seyed, A., Seyed, A., Duman, S., Fatemeh, F., Hossain, J., Mahboubeh, H. 2011. Seroprevalence of Toxoplasmosis in HIV+/AIDS Patients in Iran. Acta Med Iranica. 49: 213-218. 